\section{Liver - basic}

PARADOXICAL UP-REGULATION OF CHOLESTEROL 7a-HYDROXYLASE (C7aH) FOLLOWING COMMON BILE DUCT LIGATION (CBDL). Z.R. Vlahcevic' S.K. Jairath', M.P. Jones', W.M. Pandak', D.M. Heuman', and P.B. Hylemon ${ }^{2}$. Depts. of Medicine' and Microbiology', MCVNCU and MCGuire VAMC, Richmond,VA

Background: In rats following CBDL, alterations of hepatic homeostasis include marked increase in hepatic and serum bile acids (BA) which are coupled with paradoxical up-regulation of $\mathrm{C} 7 \mathrm{aH}$ specific activity (SA). HMG-CoA-reductase (HMGCOAR) SA is also up-regulated in face of increased microsomal and serum cholesterol (XOL). Specific Aims: TO define the mechanism responsible for paradoxical increase of C7aH SA in cholestasis. Hypothesis: The paradoxical increase in $\mathrm{C} 7 \mathrm{aH}$ may be the result of an increase in HMGCOAR, and/or failure to absorb an unidentified intestinal factor (IF) which normally represses $C 7 a \mathrm{H}$, and needs BA for absorption. The first hypothesis was tested in rats with CBDL by administering lovastatin (LOV); the second hypothesis was tested in: a) CBDL (no bile flow through intestine); and b) a single hepatic duct ligation (HDL) in which bile flow through the intestine was present. Methods: Male SD rats underwent sham surgery, CBDL or HDL. On day 7, rats were sacrificed and livers harvested. One group of rats with CBDL were administered LOV $\left(1 \mathrm{mg} / \mathrm{kg}^{\left.-\mathrm{h}^{-1}\right)}\right.$ IV for the final 24 hours.

Results:

\begin{tabular}{|c|c|c|c|c|c|}
\hline \multirow[t]{2}{*}{ Results: } & \multirow{2}{*}{ CBDL' } & \multirow{2}{*}{$C B D L+L O V^{2}$} & \multicolumn{3}{|c|}{$\mathbf{H D L}^{\prime}$} \\
\hline & & & $\begin{array}{l}\text { Ligneas } \\
\text { Lober }\end{array}$ & BDE & $\begin{array}{c}\text { Noor } \\
\text { higued } \\
\text { lobe }\end{array}$ \\
\hline $\begin{array}{l}\text { C7aH } \\
\text { HMGCANR } \\
\text { SERUM BA }\end{array}$ & $\begin{array}{l}222 \pm 60 x^{\circ} \\
3255^{\circ} \\
4000 \pm 84 x^{\circ}\end{array}$ & $\begin{array}{c}78 \pm 308 \\
100 \pm \pm 29 x \\
68 \pm 21 \times\end{array}$ & 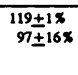 & $533 \pm 66 x$ & $\begin{array}{c}67 \pm 198 x \\
110 \pm 16 x\end{array}$ \\
\hline microver & $185 \pm 5$ & $88 \pm 7 x$ & $134 \pm 7 x$ & & \\
\hline
\end{tabular}

Conclusion: Inhibition of HMGCOAR with LOV in CBDL rats resulted in small decrease of $\mathrm{C} 7 \alpha \mathrm{H}$ SA suggesting that up-regulation of $\mathrm{C} 7 \alpha \mathrm{H}$ in cholestasis is due only in small part to increase of HMGCoAR SA. Failure of $\mathrm{C} 7 \alpha \mathrm{H}$ SA to increase in the obstructed hepatic lobe following HDL ligation suggests that the intestinal flux of BA and/or putative IF are necessary for expression of negative BA feedback control.

EXPRESSION OF IL-6-RECEPTOR MRNA IN RAT LIVER KUPFFER CELLS. DIFFERENTIAL MODULATION BY CYTOKINES, DEXAMETHASONE AND PROSTAGLANDIN $E_{2}$

RolfHOEFMANN, Hans-Peter HENNINGER, Agnes SCHULZE-SPECKING and Karl DECKER. Biochemisches Institut, Albert-Ludwigs-Universität, Hermann-Herderstr. 7, D(W)-7800 Freiburg i.Br., Germany.

Interleukin-6 is a multifunctional cytokine involved in a variety of regulatory immune responses. It is the principle cytokine responsible for regulation of the acute-phase proteins by the liver. This concept implies coordinated expression of this cytokine, their effector genes and the fine tuning of the specific receptors. In accordance to the multifunctional properties of $I L-6$, low numbers of specific receptors were reported on hepatocytes. However, knowledge accumulates regarding II-6 effects on liver target cells, while little is known about possible effector cells.

Male Wistar rats (250-300 g) fed ad libinum were used throughout. Kupffer cells (KC) were isolated by pronase-collagenase perfusion followed by centrifugal elutriation. Kupffer cells were maintained in primary culture with RPMI 1640 medium containing 30\% heat-inactivated newborn-calf serum. After $72 \mathrm{~h}$ in culture, they were exposed for $0,1 \mathrm{~h}, 2 \mathrm{~h}, 4 \mathrm{~h}, 8 \mathrm{~h}, 16 \mathrm{~h}$ and $24 \mathrm{~h}$ to $100 \mathrm{ng} / \mathrm{ml}$ LPS (S. minnesota), TNF- $\alpha, \mathbb{L}-1 \mathrm{~B}$, IFN- $\gamma$, IL-6, PMA, dexamethasone, $\mathrm{PGE}_{2}$ and cAMP. Total RNA was subsequently isolated, and IL-6 receptor mRNA expression was determined by semiquantitative PCR. For this purpose high-performance liquid chromatography (HPLC) was used to quantitate $\mathrm{PCR}$ products.

We found downregulation of IL-6 receptor mRNA in Kupffer cells which were, stimulated with IL-6, LPS, TNF- $\alpha$, IL-1B, IFN- $\gamma$ and phorbol ester (PMA). Since we detected increased mRNA levels for IL -6 after LPS and IFN- $\gamma$ stimulation, our results indicate an autocrine mechanism by which KC downregulate their surface receptors for IL-6. Preliminary results for IL1B, TNF- $\alpha$ and PMA show a similar tendency. Surprisingly IL-6 receptor mRNA was upregulated after $\mathrm{PGE}_{2}$, cAMP and dexamethasone but was unaffected after $\mathrm{PGD}_{2}$. In the microenvironment of the hepatic sinusoids the Kupffer cells (KC) are as the resident macrophages the most potential source of IL-6 during inflammation. According to this concept, IL -6 gene expression and $I-6$ release from $\mathrm{KC}$ into the hepatic sinusoids is likely under coordinated control. Our results demonstrate fine tuning of $\mathbb{I}-6$ receptor mRNA which is very likely important to achieve optimal immune responses. HepG2.
HEPATIC RECONSTITUTION WITH HEPATOCYTE TRANSPLANTATION FOR GENE THERAPY AND LIVER REPOPULATION. S. GUDTE, C-D. LoO, E. Aragona, R.D. Burk, P.R. Yerneni. Marion Bessin Liver Research Center, Albert Einstein College of Medicine, New York, USA.

As liver should best support hepatocyte survival, to examine hepatic reconstitution, we developed novel transplantation systems with cells expressing reporter genes. Initial studies with marked transgenic HBsAg-producing and 111 in-labeled hepatocytes showed that intrasplenic transplantation delivered $-50 \%-60 \%$ cells into liver. Also, serum HBsAg levels correlated with the number of transplanted cells. In situ hybridization with riboprobes showed that transplanted cells within the liver were distributed in periportal regions, swiftly assimilated, survived indefinitely and exhibited superior function. Using these concepts of hepatic reconstitution the feasibility of ex-vivo gene therapy with retroviral vector-modified autologous hepatocytes was tested in a rabbit model of familial hypercholesterolemia. Despite long-term amelioration of hypercholesterolemia by ${ }^{-1} 1 \%$ hepatic reconstitution, however, serum cholesterol levels were only decreased by up to $25 \%-30 \%$. Potentially, superior results could be obtained by better gene transfer, greater yield of autologous hepatocytes or augmentation of the transplanted hepatocyte mass. To examine whether hepatic regeneration in periportal areas containing transplanted cells could augment the transplanted hepatocyte mass, we used the hepatotoxin carbon tetrachloride $\left(\mathrm{CCl}_{4}^{-}\right)$; which selectively destroys perivenular hepatocytes. After $\mathrm{CCl}$ treatment, liver regeneration in mice resembled that after a $30 \%$ partia hepatectomy with DNA synthesis in periportal hepatocytes (histone $\mathrm{H} 3$ mRNA expression and ${ }^{3} \mathrm{H}$-thymidine incorporation). To augment the transplanted hepatocyte mass, after 8 weeks of transplanting $2 \times 10^{6}$ transgenic HBV hepatocytes, 6 -congeneic mouse recipients were given i.m. $\mathrm{CCl}_{4}$ in 3 cycles, separated by 3 weeks each. This caused significant increases in serum HBsAg (baseline, $143 \pm 118 \mathrm{ng} / \mathrm{ml}$; after the first dose of $\mathrm{CCl}_{4}, 162 \pm 111 \mathrm{ng} / \mathrm{ml}, p=N$.S.; after the second dose, $254+128 \mathrm{ng} / \mathrm{ml}, p<0.001$; after the third dose and up to the 36 week duration of the experiment, $251+115 \mathrm{ng} / \mathrm{ml}, \mathrm{p}<0.001$ ). In contrast, in 3 control recipients not treated with $\mathrm{CCl}$, serum $\mathrm{HBsAg}$ remained in a steady range with no incremental change. In situ hybridization showed HBsAg mRNA-expressing transplanted hepatocytes in the liver of recipients. An ability to augment their mass indicates that transplanted hepatocytes retain a proliferative potential. These results demonstrate that hepatic reconstitution has significant potential for ex-vivo gene therapy, as well as for treating acute liver failure.

THE HEPATIC ACUTE PHASE PROTEIN ALPHA-1-ANTTTRYPSIN INHIBITS TRANSFERRIN RECEPTOR BINDING, GROWTH, AND PROLIFERATION OF THE HEPATIC TUMOR CELLS HEPG2 I.Graziadei, R.Kaserbacher, A.Böhm, W.Vogel. Dept. of Internal Medicine,University of Innsbruck, Austria.

Iron uptake is required for the growth of normal and neoplastic cells because of its importance in several biologic reactions, such as DNA-synthesis, oxidative phosporylation, etc. The iron uptake is mediated by specific cell surface transferrinreceptors (tfR) which bind iron loaded transferrin (t) with high affinity. It was shown that monoclonal antitransferrin receptor antibodies (ATRA) which interfere with tfmediated iron uptake by blocking tfR binding reduced the growth of several tumor cells. In a recent in vitro study we showed that alpha-1-antitrypsin ( $\alpha 1-\mathrm{AT})$, which is mainly produced by hepatocytes, inhibits tfR binding. (Biochem J, 1993, 290, 109).

In the present study we addressed the question if the interaction of the hepatic acute phase protein al-AT with tRR binding has biological implications similiar to the ones found with ATRA. For this reason we investigated the effect of $\alpha 1-A T$ on tfR binding and the effect on growth and proliferation of the human hepatic tumor cell line

HepG2 cells were grown in RPMI 1640 supplemented with $10 \% \mathrm{FCS}$ at $37^{\circ} \mathrm{C}$ in a humidified $5 \% \mathrm{CO}_{2}$ atmosphere. For binding inhibition-, equilibrium saturation- and kinetic studies $1.2-2.5 \times 10^{6}$ cells were incubated with-120-220-pM $\left[{ }^{125}\right]$-tf-at $37^{\circ} \mathrm{C}$ or $4^{\circ} \mathrm{C}$. To destinguish cell surface bound from internalized $\left[{ }^{125}\right]$-tf we employed the pronase technique. After incubating the cells with increasing amounts of a1-AT for $72 \mathrm{~h}$, the cells were counted and viability was assessed by exclusion of $0.1 \%$ eosin. To determine DNA-synthesis rate we performed $\left[{ }^{3} \mathrm{H}\right]$-thymidine incorporation assays. The receptor binding of [ ${ }^{125} \mathrm{\eta}$-tf was inhibited by $\alpha .1-\mathrm{AT}$ in a monophasic manner with an $\mathrm{Ki}$-value of $10.32 \pm 2.3 \mu \mathrm{M}(\mathrm{n}=3)$ [mean \pm S.E. of $\mathrm{n}$ exp.]. In saturation assays the presence of $\alpha 1-\mathrm{AT}$ caused a significant increase of the $\mathrm{KD}$-value while the maximal density of binding sites was not changed. The increase of the $\mathrm{KD}$-value was due to a decrease of the association rate constant as shown in kinetic studies. The internalization of [ ${ }^{125} \Pi$-tf was also selectively inhibited by $\alpha 1-\mathrm{AT}$.

The growth of HepG2 cells was reduced by $\alpha 1-\mathrm{AT}$ in a dose dependent fashion up to maximal $50.2 \pm 3.4 \%(n=3)$ at a dose of $100 \mu \mathrm{M}$. DNA-synthesis was not inhibited to the same degree. The reduction of $\left[{ }^{3} \mathrm{H}\right]$-thymidine incorporation by $100 \mu \mathrm{M} \propto 1-\mathrm{AT}$ was maximal $30.2 \pm 3.6 \%(n=3)$.

In summary, we could demonstrate that the hepatic acute phase protein $\alpha$ l-AT reduced in high physiological concentrations the cell growth and proliferation of the hepatic tumor cells HepG2 by interfering with tf mediated iron uptake. 
TARGETING OF 5-FLUOROURACIL TO THE LIVER USING A NOVEL DISACCHARIDE ADDUCT.

N. Davies. J. Yates, H. Kynaston, B. Taylor,T. Cooke, H. Hamad,C.H. Bamford, S.A. Jenkins, Departments of Surgery and Bioengineering, Royal Liverpool University Hospital, Liverpool, U.K.

Targeting of 5-fluorouracil (5FU) to the liver of patients with hepatic metastases may maximise tumour kill, minimise systemic side effects and possibly improve survival. The aim of this study was to compare the uptake of 5FU and a novel 5-FU disaccharide (galactose and fructose) adduct by normal liver tissue and hepatic tumour in rats.

Hepatic tumour was induced in BD1XZ rats by an intraportal injection of $1 \times 10^{7} \mathrm{~K} 12 / \mathrm{TR}$ adenocarcinoma cells. Groups of rats with hepatic tumour received $5 \mathrm{mg}{ }^{14} \mathrm{C}$-FU or ${ }^{14} \mathrm{C}$-5FU adduct (22mg) containing the same concentration of 5FU and blood samples removed at $10 \mathrm{~min}$ intervals. One hour after administration of the 5FU or adduct the rats were killed, the visceral organs removed, weighed and the radioactivity measured in a scintillation counter.

The hepatic uptake of SFU and the adduct was not significantly different between the two groups of animals $(p>0.05$ Student's test). However, the uptake of adduct by tumour tissue was four times greater than $5 F U(4226 \pm 190$ v $1003 \pm 190 \mathrm{cpm} / \mathrm{g} ; \mathrm{p}<$ $0.001)$. Conversely the maximal blood level of the adduct (57.9+ $0.65 \mathrm{cpm} / \mathrm{ml})$. was significantly. less than $5 \mathrm{FU}(212.7 \pm 2.9 \mathrm{cpm} / \mathrm{ml})$.

The results of this study indicate- that coupling of SFU to a simple carbohydrate containing a galactose moiety selectively targets the cytotoxic to hepatic adenocarcinoma and may therefore potentiate tumour kill and improve survival.
OII/6 1245

BIOCHEMICAL AND 31P-NMR SPECTROSCOPIC EVALUATION OF IMMOBILIZED PERIFUSED RAT HEPATOCYTES. RELATION TO THE NUTRITIONAL STATUS. A. Gasbarrini^\# $\sim$ P. Caraceni^^, M. Bernardi^, A. Facchini\#, G. Gasbarrini^, H. Farghali $\sim$, A.B. Borle and D.H. Van Thiel $\sim$. Patologia Medica I^ and Laboratorio di Immunologia e Genetica (IOR)\#, University of Bologna, Italy; Dept of Surgery , University of Pittsburgh, USA.

The effect of fasting on the concentration of ATP, phosphorylation potential, $\mathrm{Ca} 2+, \mathrm{Na}+, \mathrm{Mg} 2+$ and $\mathrm{pH}$ was studied in hepatocytes isolated from fed or $24 \mathrm{hrs}$ fasted rats. After isolation, the cells were imbedded in agarose gel threads and continuously perfused with Krebs-Henseleit bicarbonate buffer. Cytosolic free calcium (Cai2+) was measured in real time with the photoprotein aequorin; intracellular free sodium (Nai+) and intracellular $\mathrm{pH}$ (PHi) with the fluorescent dyes SBFI-AM and BCECF-AM, respectively; intracellular free magnesium (Mgi2+), intracellular ATP (expressed as the b-ATP/external standard ratio) and phosphorylation potential (approximated by the ATP/inorganic phosphate ratio) by 31P-NMR spectroscopy in real time. In fasted rats, intracellular ATP and cell energy potential were significantly depressed. compared with fed controls: $0.7 \pm 0.16$ vs $1.35 \pm 0.15$ $(p<0.005)$ and $0.20 \pm 0.02$ vs $0.37 \pm 0.05(p<0.005)$, respectively. On the other hand, $\mathrm{Nai}+$ and $\mathrm{Cai2}+$ were significantly higher in fasted rats compared to fed controls: $27.7 \pm 2.2$ vs $16.3 \pm 2.8 \mathrm{mM}(p<0.02)$ and $227 \pm 16$ vs $138 \pm 13 \Omega M(p<0.05)$, respectively. Intracellular $\mathrm{pH}$ and Mgi2+ were not different in the two groups: $7.32+0.4$ vs $7.33 \pm 0.9$ and $0.51 \pm 0.04 \mathrm{mM}$ vs $0.50 \pm 0.09 \mathrm{mM}$, respectively.

These results show that fasting significantly decreases the intracellular ATP concentration and the hepatocyte phosphorylation potential. The reduced cell energy level is probably the cause of the raised resting levels of $\mathrm{Nai}+$ and $\mathrm{Cai2}+$.
HEPATIC STIMULATOR SUBSTANCE AND CARBON TETRACHIORDE STIMULATE $c$-fos, $c$-jun ONCOGENE EXPRESSION IN RAT LIVER. Q.Shao.J.Mei* W.Q.Chang. M.H.Mei. Dept. of Physiology, Dalian Medical College,Dalian, P.R.China and *Dept. of Medical and Physiological Chemistry, University of Lund, Sweden.

Hepatic stimulator substance (HSS) was extracted from the new bom calf according to the method of LaBrecque.HSS was injected into the rats which had been partial (34\%) hepatectomied and the incorporation of ${ }^{3} \mathrm{H}$-thymidine into liver DNA was determined for bioassay of HSS. The results showed that ${ }^{3} \mathrm{H}$ thymidine incorporation into the liver of rats injected with HSS extracted from calf was increased about seven-fold compared to the saline control group.Carbon tetrachloride $\left(\mathrm{CCl}_{4}\right)$ was mixed with soybean oil vehicle in concentration of $20 \%$ and a single dose infusion into the stomach of rat at a dose of $10 \mathrm{ml} / \mathrm{kg}$ body weight was given.By means of Western blot method and immunocytochemistry (ICC) protocal, c-fos and c-jun oncogene expression of liver was investigated in adult rats treated with $\mathrm{HSS}$ or/and $\mathrm{CCl}_{4}$.

It was found that in assay of Westem blot, the levels of product of $\mathrm{c}$-fos/c-jun was sightly increased in adult rat quiescent hepatocytes induced by HSS (20 $\mathrm{mg} / \mathrm{kg}$ body weight, i.p.). However, when HSS combined with $\mathrm{CCl} 4$ the appearance of Fos/Jun occured significantly, i.e.the Fos/Jun-related antigen were enhanced by HSS markedly. CCl4 may induced the appearance of Fos/Jun after administration at $10 \mathrm{~min}$, significantly appeared at $30 \mathrm{~min}$, and persisted in $60 \mathrm{~min}$ then disappeared, it was called immediate expression. Thereafter; Fos/Jun was reappeared at $8 \mathrm{~h}$ after hepatocyte injury and persisted in $24 \mathrm{~h}$ or more, it was called sequential expression of oncogene. The ICC technique showed that Jun positive cells are localized in hepatic parenchymal cells that closed to the zone of central vein in liver.

Based on the above mentioned data we suggest that HSS and $\mathrm{CCl}_{4}$ could stinulate c-fos/c-jun oncogene expression and HSS enhanced $\mathrm{CCl} 4$-induced oncogene expression. The immediate and sequential c-fos/c-jun oncogene expression during the prereplicative period of $\mathrm{CCl}_{4}$-injured liver could reflect events associated with liver cells enter into the cell cycle and these expressions were possibly related with direct and indirect injury of $\mathrm{CCl}_{4}$, the later was via the free radicals produced by the P450 enzyme system. Also, it is served as a marker to identify a specific humoral factor(s) involved in liver regeneration. Both of $c$-fos and $c$-jun oncogene expression showed that liver injury and regreneration occur side by side.

$011 / 8222$

INFLUENCE OF TAUROCONJUGATED BILE SALTS (BSS) ON DNA SYNTHESIS IN CULTURED RAT HEPATOCYTES

Barone M., Romanelli D., Angelini A., A. Francavilla. Dept. of Gastroenterolgy, Univ. di Bari, Italy.

It has been previously demonstrated by us that cholate (CA), ursodeoxycholate (UDCA), chenodeoxycholate (CDCA) and deoxycholate (DCA) significantly stimulate proliferation of cultured rat hepatocytes $(C A>U D C A>C D C A>D C A$ ) with a maximal response at $60 \mu \mathrm{M}$. Since, in vivo, these bile salts are present mainly as glico or tauroconjugated, in this study we evaluated the effect of tauroursodeoxycholate (TUDCA) a BS already used in the treatment of liver disease, on hepatocyte proliferative activity in vitro and compared liver disease, on hepatocyte proliferative activity in

it with that obtained by other tauroconjugated forms.
Hepatocytes, obtained from $F-344$ male rats, were isolated by means of the Jertle's modification of the in situ two-step collagenase perfusion technique of Seglen, suspended in Minimum Essential Medium (MEM) supplemented with insulin $\left(10^{-7} \mathrm{M}\right)$ and $5 \% \mathrm{FCS}$, plated in $35 \mathrm{~mm}$ Falcon dishes $\left(2.5 \times 10^{5} / 1.5 \mathrm{ml} / \mathrm{dish}\right)$, and incubated at $37^{\circ} \mathrm{C}$ in a $5 \%$ $\mathrm{CO}_{2}$ humidified atmosphere. After a 3-hour attachment period, the medium was replaced by serum-free medium containing the various medium was replaced.by serum-free medium containing the various
bile salts to be tested. After $24^{\mathrm{h}},\left[{ }^{3} \mathrm{H}\right]$-thymidine $(7 \mu \mathrm{Ci} / \mathrm{dish})$ was added to the culture medium. Forty-eight hours after the beginning of the experiment hepatocytes were harvested to evaluate $\left[{ }^{3} \mathrm{H}\right]$-thymidine incorporation. Our results

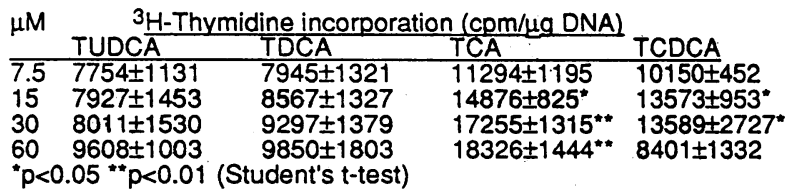

which are the mean $\pm S D$ of 4 different experiments, demonstrate that only taurocholate and taurochenodeoxycholate produced a significant increase of DNA synthesis compared to controls $(7201 \pm 1140 \mathrm{cpm} / \mu \mathrm{g}$ DNA). These results indicate a possible implication of primary bile salts in the abnormal proliferation of hepatocytes associated to cholestatic conditions. 